\title{
Taxonomic Study of Suborder Calcaxonia (Alcyonacea: Octocorallia: Anthozoa) from King Sejong Station, Antarctic
}

\author{
Jun-Im Song ${ }^{1, *}$, Sung-Jin Hwang ${ }^{1}$, Haewon Moon ${ }^{2}$, In-Young $\mathrm{An}^{2}$ \\ ${ }^{1}$ Division of EcoScience, Ewha Womans University, Seoul 120-750, Korea \\ ${ }^{2}$ Division of Polar Life Sciences, Korea Polar Research Institute, KORDI, Incheon 406-840, Korea
}

\begin{abstract}
Some gorgonians in the families, Primnoidae and Isididae within the suborder Calcaxonia were collected from subtidal zones between depths of 10 and $45 \mathrm{~m}$ in the coastal regions of King Sejong Station $\left(62^{\circ} 13^{\prime} \mathrm{S}, 058^{\circ}\right.$ $47^{\prime} \mathrm{W}$ ), Korea Polar Research Institute of Korea Ocean Research and Development Institute (KORDI) by SCUBA diving from 2009 to 2011. Three species in the Primnoidae, Arntzia gracilis (Molander, 1929), Thouarella (Thouarella) antarctica (Valenciennes, 1846) and Onogorgia nodosa (Molander, 1929), and also one species in the family Isididae, Tenuisis microspiculata (Molander, 1929) are newly recorded to octocorallian fauna in Marian Cove and Potter Cove of King George Island. These four species have been described in detail.
\end{abstract}

Keywords: Octocorallia, Calcaxonia, Primnoidae, Isididae, King Sejong Station, Antarctic

\section{INTRODUCTION}

Suborder Calcaxonia belongs to the order Alcyonaria within the subclass Octocorallia and includes five gorgonian families, of which two families, Primnoidae and Isididae have been introduced from King Sejong Station $\left(62^{\circ} 13^{\prime} \mathrm{S}, 058^{\circ}\right.$ $47^{\prime} \mathrm{W}$ ), Korea Polar Institute (KOPRI) of Korea Ocean Research and Development Institute (KORDI) for the Korea Antarctic Research Program on King George Island in the present study. The former Primnoidae comprising more than 233 species within 36 genera has the axis revealed undulating concentric layers of calcified material embedded in gorgonin, and the latter Isididae possesses the characteristic axis composed of alternating horny nodes and nonspicular calcareous internodes. In a series of taxonomic studies on anthozoans from King Sejong Station, KOPRI, three species in Primnoidae and one in Isididae have newly been added to the octocorallian fauna.

\section{MATERIALS AND METHODS}

All specimens examined in this study were collected from subtidal zones in the coastal regions of King Sejong Station, KOPRI between depths of 10 and $45 \mathrm{~m}$ from two sites, which were the Marian Cove and a site in Potter Cove of King George Island, by SCUBA diving from December 2009 to January 2011 (Fig. 1). Information on the detailed collecting sites is shown in Table 1. The specimens were anesthetized with menthol for $6-8 \mathrm{~h}$, and then fixed in $4-5 \%(\mathrm{v} / \mathrm{v})$ formalin with seawater. After that, they were washed with tap water, and preserved in $70 \%$ alcohol (v/v).

For identification, each specimen was examined for external and internal morphological characteristics such as growth form, branching pattern and size on each part of colonies, arrangement of polyps on stem and branches, and also coloration, anthostele, shape and size of sclerites in polyps and coenenchymes under the stereomicroscopes (Semi SV-6 and SV-11; Carl Zeiss, Jena, Germany and S8APO; Leica, Wetzlar, Germany) and light microscope (Eclipse 80i; Nikon Co., Tokyo, Japan). The color of each part was recorded with a color code based on the color chart (New Color Cards 199b; Japan Color Research Services Company, Japan). To examine the sclerites, a small part of tissue from the each body part was dissolved in a diluted solution of the clorax for five minutes. In addition, the white sclerites of the polyp head were (c) This is an Open Access article distributed under the terms of the Creative Commons Attribution Non-Commercial License (http://creativecommons.org/ licenses/by-nc/3.0/) which permits unrestricted non-commercial use, distribution, and reproduction in any medium, provided the original work is properly cited.

pISSN 2234-6953 eISSN 2234-8190
*To whom correspondence should be addressed

Tel: 82-2-3277-2364, Fax: 82-2-3277-2385

E-mail: jisong@ewha.ac.kr 


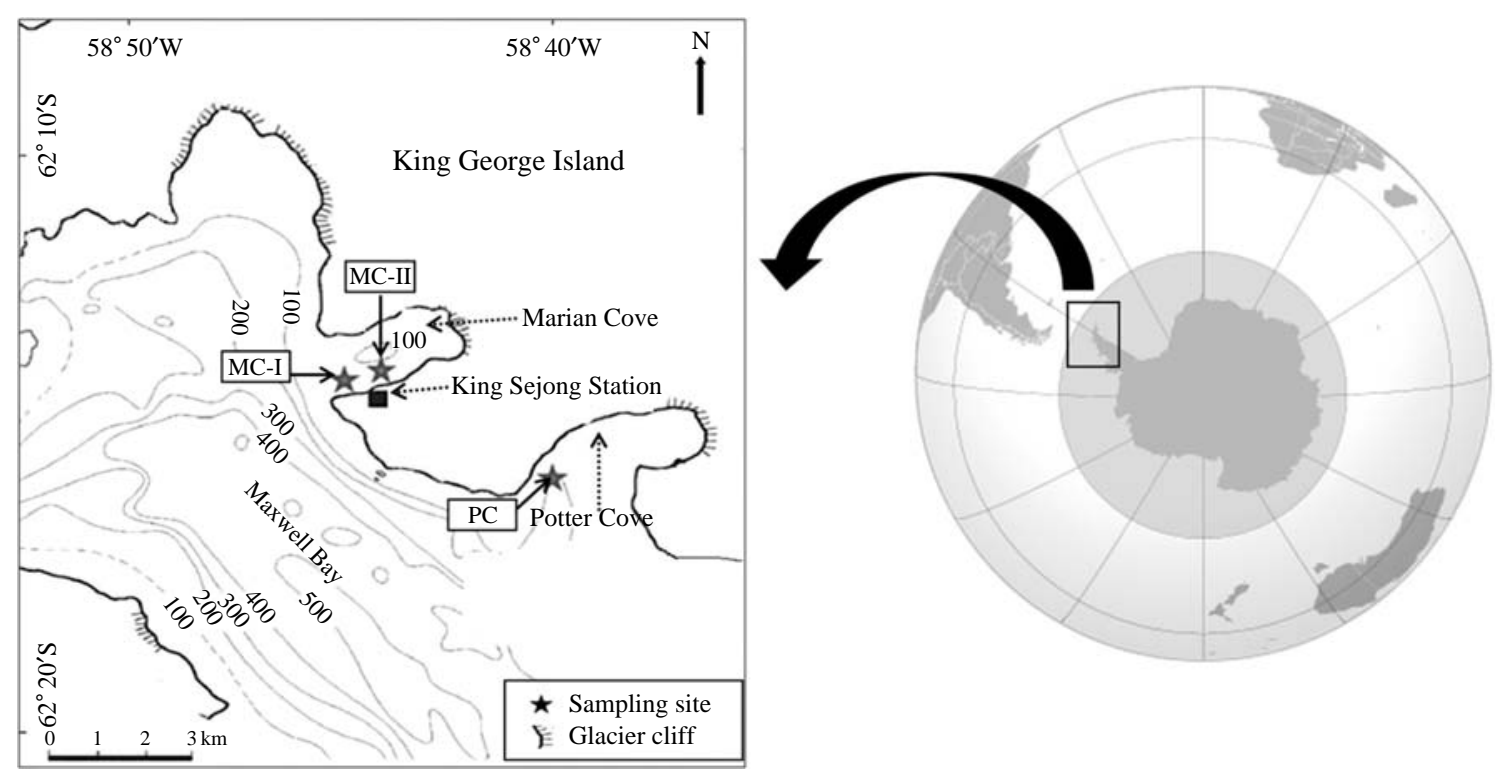

Fig. 1. Sampling sites in the King Sejong Station, Korea Polar Institute (KOPRI) from 2009 to 2011. MC-I, Marian Cove I; MC-II, Marian Cove II; PC, Potter Cove.

Table 1. Information of collection sites in King Sejong Station, Korea Polar Institute (KOPRI)

\begin{tabular}{lccc}
\hline \multicolumn{1}{c}{ Site } & $\begin{array}{c}\text { Symbol } \\
\text { of site }\end{array}$ & GPS & $\begin{array}{c}\text { Depth } \\
(\mathrm{m})\end{array}$ \\
\hline Marian Cove I & MC-1 & $62^{\circ} 13^{\prime} 350^{\prime \prime} \mathrm{S}, 058^{\circ} 47^{\prime} 289^{\prime \prime} \mathrm{W}$ & $30-35$ \\
Marian Cove II & MC-II & $62^{\circ} 13^{\prime} 190^{\prime \prime} \mathrm{S}, 058^{\circ} 46^{\prime} 851^{\prime \prime} \mathrm{W}$ & $30-35$ \\
Potter Cove & PC & $62^{\circ} 14^{\prime} 276^{\prime \prime} \mathrm{S}, 058^{\circ} 42^{\prime} 885^{\prime \prime} \mathrm{W}$ & $30-45$ \\
\hline
\end{tabular}

stained with a mixture of methylene blue (one or two drops) and ethanol for the visualization of anthostele.

The living calcaxoian colonies under water were photographed with a digital camera (5060-WZ; Olympus, Tokyo, Japan) with underwater housing (Patima-7070; Patima Uw_ Eng Co. Ltd, Seoul, Korea). The specimens were photographed with a digital camera (G7; Canon Inc., Tokyo, Japan) before fixation. Photographs of the arrangement of polyps to branches and the anthostele of polyps were taken by a stereomicroscope (Semi SV-11; Carl Zeiss) mounted with a digital camera (5060-WZ; Olympus) and a second stereomicroscope (S8APO; Leica) with another digital camera (DFC 290; Leica). Next, the size of polyps, and also the interval and angle of polyp head to branchlet were measured using an image analyzer (Motic Image Plus 2.0; Motic China Group Co., Xiamen, China and LAS Version 3.6; Leica). Images of sclerites were taken with a light microscope (Eclipse $80 \mathrm{i}$; Nikon Co.) mounted with a camera (DS-5Mc; Nikon Co.), and then the size of sclerites were calculated with an image analyzer (NIS-Elements BR 3.0; Nikon Co.). In addition, an image editing program (HeliconFocus 5.1 Pro; Helicon Soft Ltd., Kharkov) was used to create one completely focused image of a sclerite from several partially focused images by combining the focused areas.

For identification and classification, Cairns and Bayer's (2009) generic revision of the Primnoidae and also Bayer and Stefani's (1987) classification of the Isididae were employed. The samples examined in this study have been deposited in the Korean Coral Resource Bank (KCRB), Ewha Womans University and some of them are stocked in the Korea Polar Research Institute of KORDI.

\section{SYSTEMATIC ACCOUNTS}

Phylum Cnidaria Hatschek, 1888

Class Anthozoa Ehrenberg, 1834

Subclass Octocorallia Haeckel, 1866

Order Alcyonacea Lamouroux, 1816

Suborder Calcaxonia Grasshoff, 1999

Diagnosis. Colonies with a solid axis without a central hollow core. Axis composed of large amount of non-scleritic calcareous material between horny fibers or present as a central core or as solid intermodal sections alternating with nodes and pure gorgonin in a segmented axis. Solid calcareous internodes white or colored. In some families, axis having a green to golden metallic or iridescent sheen. 

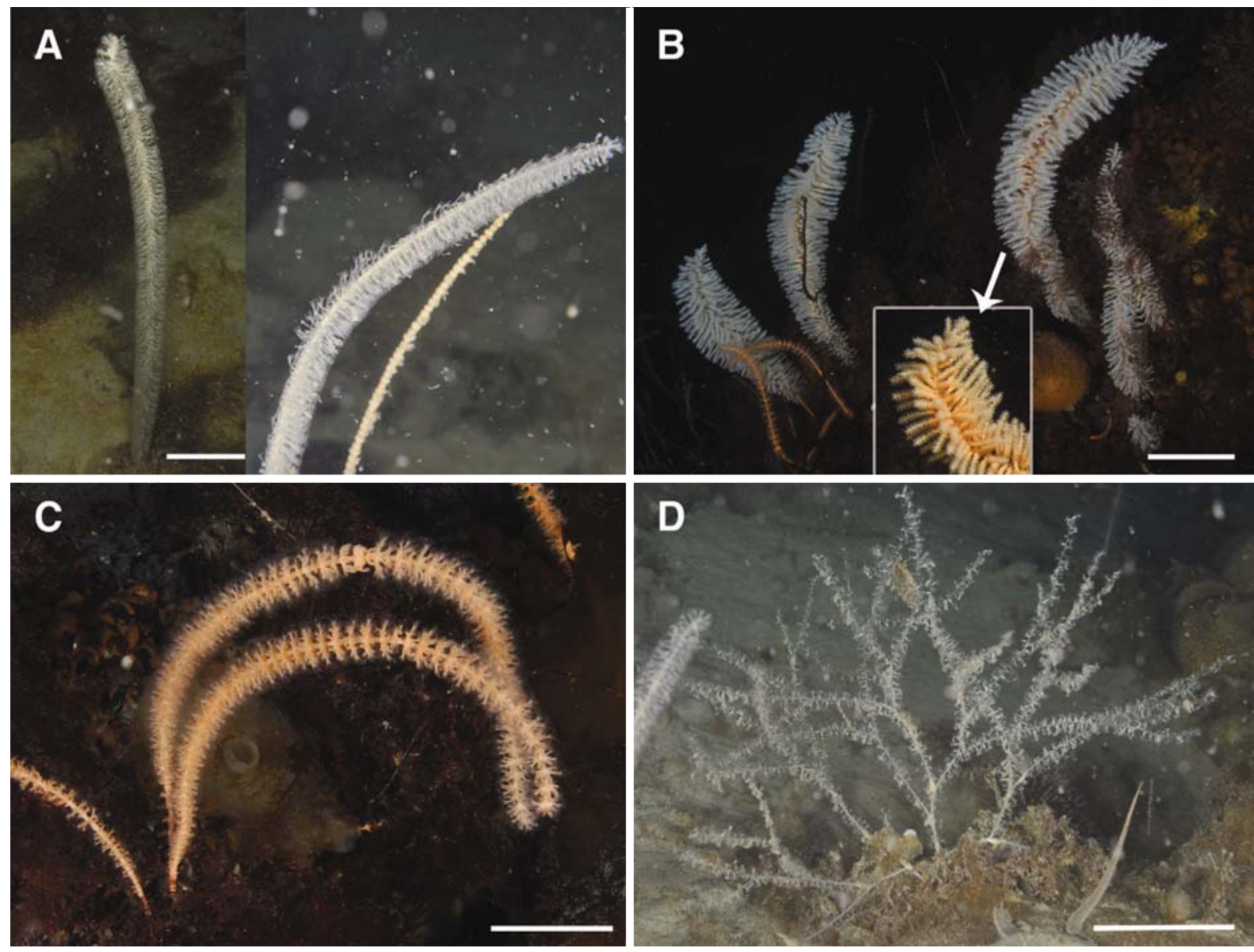

Fig. 2. Calcaxonian colonies. A, Arntzia gracilis, left, a whole colony; right, an enlargement of upper part; $B$, Thouarella (Thouarella) antarctica, an enlargement of upper part of colony ( $\downarrow$ ); C, Onogorgia nodosa; D, Tenuisis microspiculata. Scale bars: A, C, D=5 cm, $\mathrm{B}=10 \mathrm{~cm}$.

Family Primnoidae Milne Edwards, 1857

Diagnosis. Axis reveals undulating concentric layers of calcified material embedded in gorgonin, resulting from a longitudinal pattern of calcification, without a chambered central core. Colonies branched in a variety of manners or unbranched, usually firmly attached to substrate by a calcareous discoidal holdfast. Polyps non-retractile, calyces occurring in a variety of arrangements and orientations.

\section{Genus Arntzia López-González, Gili and Orejas, 2002}

Diagnosis. Flagelliform, unbranched Primnoidae. Colonies not densely spiculated. Polyps tall, cylindrical, standing almost vertical from axis, arranged in whorls. Bases of polyps fused basally. Basal brooding part of polyps fused forming a common brood-chamber within axial coenenchyme. Eight distalmost opercular scales, larger than marginal or submar- ginal scales. Body completely covered by scales, except for proximal and basal parts of adaxial side of polyps.

Arntzia gracilis (Molander, 1929) (Table 2, Figs. 2A, 3, 4) Primnoella gracilis Molander, 1929: 63, figs. 17-18, Pl. 1,

fig. 2 (cited from Cairns and Bayer, 2009).

Arntzia gracilis López-González et al., 2002: 385, figs. 1-7;

Cairns and Bayer, 2009: 33, fig. 6a-f.

Material examined. Antarctic: Marian Cove I, 1 ind., 23 Dec 2009, 30-35 m deep; Marian Cove I, 1 ind., 24 Dec 2009, 3035 m deep; Marian Cove I, 1 ind., 3 Jan 2011, 30 m deep.

Description. Colonies unbranched, flagelliform, whip-like (Fig. 2A). Specimens with thin holdfast up to $5 \times 4 \mathrm{~mm}$ in diameter, $250 \times 3-330 \times 4 \mathrm{~mm}$ (height $\times$ diameter) including stalks $10-35 \mathrm{~mm}$ long. Axis mostly $0.6-1.7 \mathrm{~mm}$ in diameter, 1.5-1.7 $\mathrm{mm}$ at stalk, $1.4-1.5 \mathrm{~mm}$ at middle part and 0.6-0.7 $\mathrm{mm}$ at upper part. 

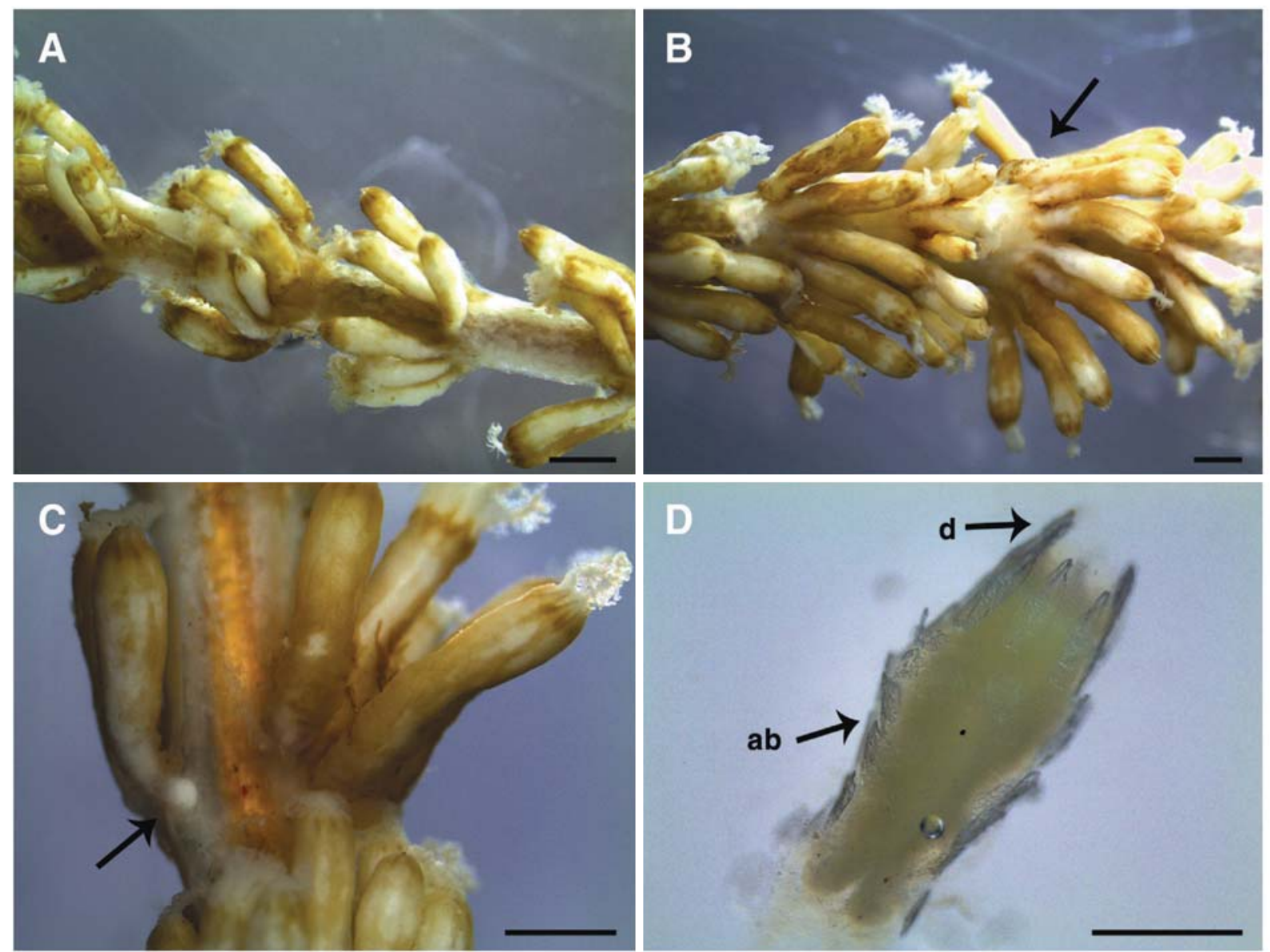

Fig. 3. Arntzia gracilis. A, Arrangement of polyps on stem; B, Polyps arranged in a whorl ( $\downarrow$ ); C, A gonad ( $\downarrow$ ) within gastrovascular cavity of polyp; D, Adaxial side of a calyx. ab, abaxial longitudinal row; d, distalmost (opercular scale). Scale bars: A-C=1 mm, $\mathrm{D}=0.5 \mathrm{~mm}$.

Table 2. Measurement $(\mu \mathrm{m})$ and shape of sclerites of Arntzia gracilis

\begin{tabular}{lcc}
\hline \multicolumn{1}{c}{ Part } & Shape & Length $\times$ Width \\
\hline Tentacle & & None \\
Polyp body & Triangular and pointed scale & $350-650 \times 110-190$ \\
$\quad$ Distalmost & Rounded or polygonal scale & $200-360 \times 150-215$ \\
Marginal & Rounded or polygonal scale & $170-260 \times 140-170$ \\
$\quad$ Middle part & Rounded or polygonal scale & $120-160 \times 110-120$ \\
$\quad$ Basal part & & $100-170 \times 50-110$ \\
Coenenchyme of stalk & Tuberculate spindle & $50-260 \times 50-260$ \\
$\quad$ Inner layer & Flat scale & $100-170 \times 60-80$ \\
$\quad$ Outer layer & Tuberculate spindle & $110-300 \times 90-240$ \\
Coenenchyme of middle part of colonies & Flat scale & \\
$\quad$ Inner layer & &
\end{tabular}

Polyps cylindrical, irregular in size, 2.0-3.0 $\times 0.5-0.7 \mathrm{~mm}$ (length $\times$ diameter), standing almost vertical from axis, arranged in whorls, and arranged 10-16 on low annular thickenings of coenenchyme at middle part of colonies, with proximal portion partially or negligibly fused, notable mainly in reproductive stages (Fig. 3C). Polyps directed upwards, but not strongly adhered to coenenchyme. About 2-5 whorls per $\mathrm{cm}$ of axial length (Fig. 3A, B). Polyps with eight longitudinal 

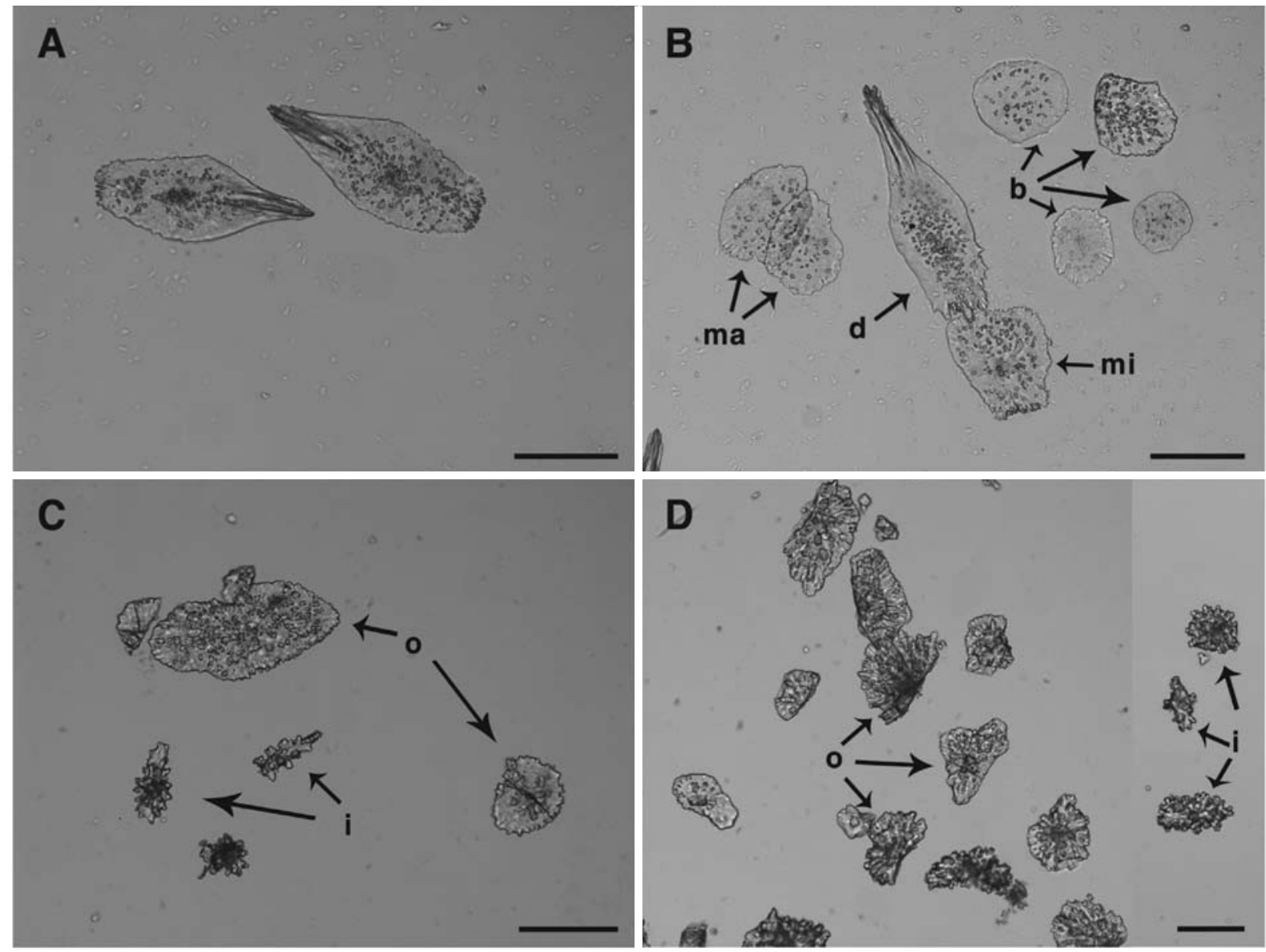

Fig. 4. Sclerites of Arntzia gracilis. A, B, Scales of polyps. A, Opercular; B, Distal, marginal, middle and basal. C, D, Sclerites of coenenchyme. C, Middle part of colony; D, Stalk. b, basal scales of polyp; d, distalmost scale; i, inner rind's spindles of coenenchyme; ma, marginal scale; mi, middle part's scales of polyp; o, opercular scale. Scale bars: $A-C=200 \mu \mathrm{m}, \mathrm{D}=100 \mu \mathrm{m}$.

rows of scales perfectly aligned on distal half of polyps, sometimes irregular arrangement or complete absence of scales on proximal half. Scales slightly overlapping, 5-7 (8) scales at two adaxial longitudinal rows (Fig. 3D), and 8-10 (11) scale at abaxial and lateral longitudinal rows.

Individuals covered by a thin layer of epidermal tissue overlain by brownish cuticle. Gonads large in size, approximately $280 \mu \mathrm{m}$ in diameter, but few number within gastrovascular cavities of polyps at middle part of colonies (Fig. 3C). Tentacles with 12-13 pairs of pinnule, 1-2 mm long.

In coloration, colonies pinkish white (itg8) in life and white in alcohol, showing brownish by thin membranous cuticle.

Distalmost scales (opercular) of polyp more or less triangular and pointed, $350-550 \times 110-190 \mu \mathrm{m}$, two adaxial scales smaller 370-395 × 120-136 $\mu \mathrm{m}$ (Fig. 4A, B). Marginal scales smaller, more or less rounded or polygonal, similar to remaining body scales (Fig. 4B). Abaxial and lateral longitudinal rows with 8-10 (11) scales (Fig. 3D), 560-648 × 190-
$220 \mu \mathrm{m}$ and 500-591 $\times 160-180 \mu \mathrm{m}$, respectively. Two adaxial longitudinal rows with 5-7 (8) scales smaller in size, 370$392 \times 120-136 \mu \mathrm{m}$, than abaxial and marginal scales. Basal and proximal portions on adaxial side of polyp body naked and markedly fleshy (Fig. 3D), Coenenchyme thick, 0.36-0.46 $\mathrm{mm}$ thick at stalk and $0.30-0.31 \mathrm{~mm}$ at middle part, with an outer layer containing sclerites like those on bodies of polyps, 50-300 × 50-240 $\mu \mathrm{m}$ (Fig. 4C, D). Inner layer, containing longitudinal stem canals, with more or less irregular rods covered by compound tubercles, $90-170 \times 50-110 \mu \mathrm{m}$. Superficial coenenchymal scale-like and inner irregular sclerites, more densely packed in smaller colonies than in larger ones. Remarks. The characteristics of our specimens mostly agree with those of López-González et al. (2002), but they differ in the number and size of scales overlapping at adaxial, lateral and abaxial longitudinal rows of polyps. This species are abundantly living at depths of 30-35 $\mathrm{m}$ in the Marian Cove I in front of King Sejong Station. 

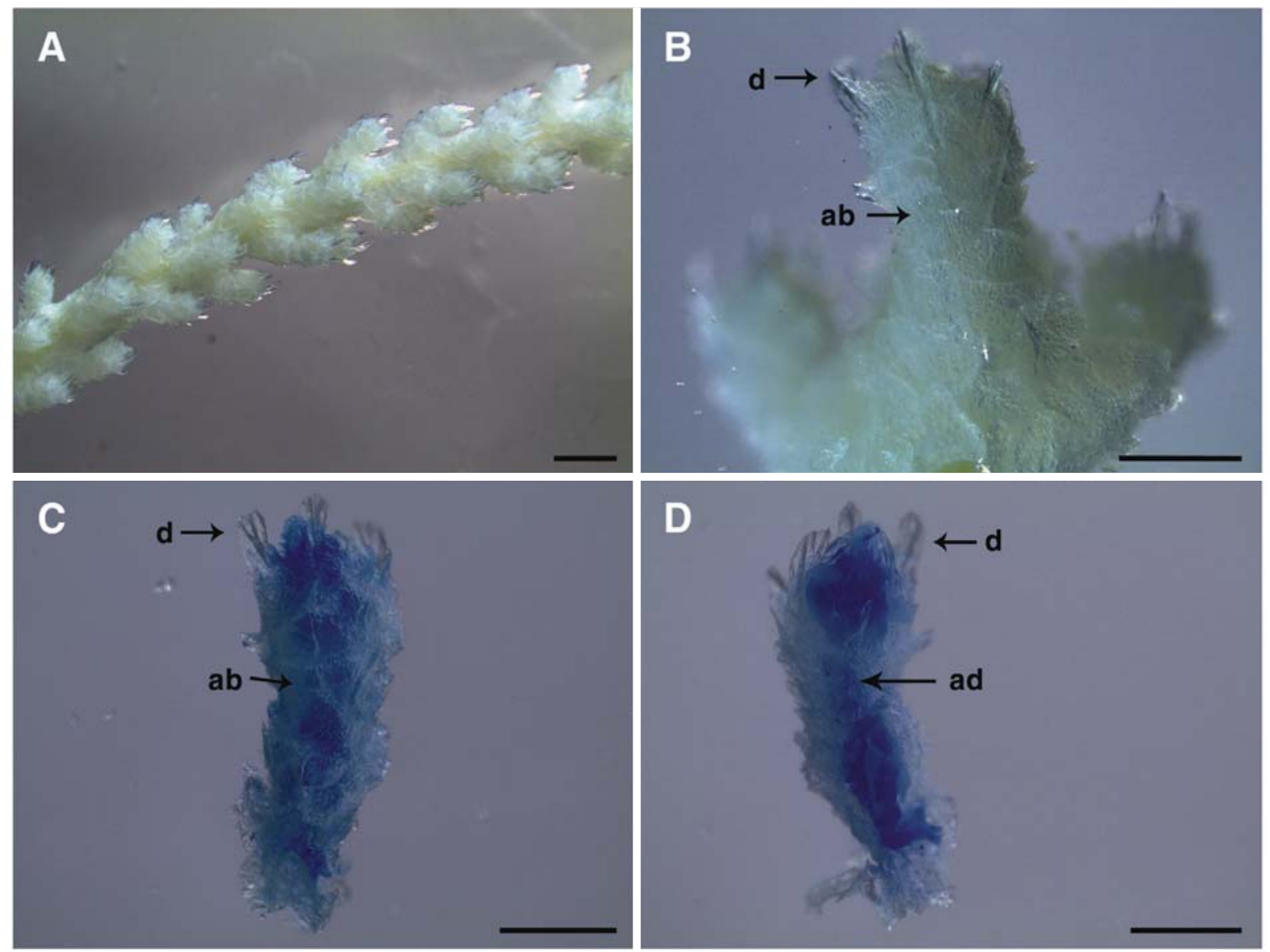

Fig. 5. Thouarella (Thouarella) Antarctica. A, Polyps on branchlet; $B$, Abaxial view of a calyx; C, Abaxial side of a calyx; $D$, Adaxial side of a calyx. ab, abaxial longitudinal row; ad, adaxial longitudinal row; d, distalmost (opercular scale). Scale bars: A=1 mm, B$\mathrm{D}=0.5 \mathrm{~mm}$

Distribution. Antarctic and Subantarctic (Weddell Sea, Scotia Arc, and Ross Sea).

\section{Genus Thouarella (Thouarella) Gray, 1870}

Diagnosis. Colonies of most species branch in a bottlebrush fashion, although two species have pinnate branching. Calyces isolated (not in pars of whorls), arranged in no apparent order on all sides of branches and stand perpendicular or inclined upward (type species) on branch.

Well-developed operculum present. Marginal scales arranged in two circles of four that alternate with one another, circumference of distal polyp not being large enough to accommodate eight adjacent marginal scales; distal margins of marginals spinose, folding over lower portion of operculars, forming a circumoperculum. Inner face of operculars and marginals bear ornate keels, each longitudinal keel bearing several smaller ridges oriented at right angles, altogether forming a foliate process; distal edges of same scales finely serrate. Polyps protected by six longitudinal rows of body wall scales, the adaxial face being covered by enlarged inner-lateral scales, resulting in complete coverage of polyp. Outer and inner faces of body wall scales radially ridged distally. Coenechymal scales in two layers; outer layer composed of irregularly shaped scales with granular outer surface; inner layer composed of small spheroids.

\section{Thouarella (Thouarella) antarctica (Valenciennes, 1846)}

(Table 3, Figs. 2B, 5, 6)

Primnoa antarctica Valenciennes, 1846: Pl. 12, fig. 2-2a (cited from Cairns and Bayer, 2009); M. Edwards, 1857: 140.

Thouarella antarctica: Wright and Studer, 1889: 65, Pl. 21, fig. 6; Versluys, 1906: 35.

Thouarella (Thouarella) antarctica: Bayer, 1956: F220; Bayer and Stefani, 1989: 455; Cairns, 2006: 177; Cairns and 

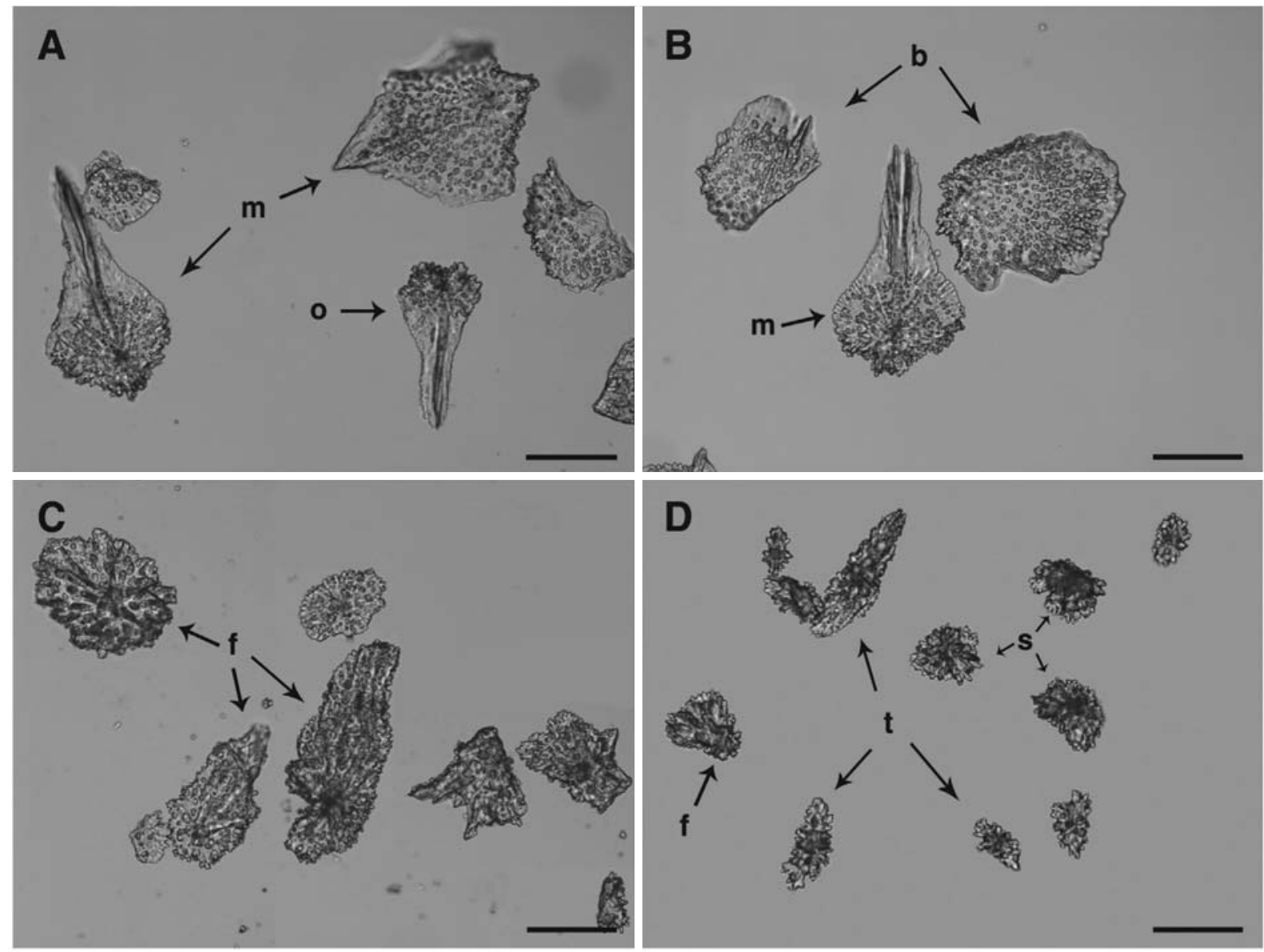

Fig. 6. Sclerites of Thouarella (Thouarella) Antarctica. A, B, Scales of polyp. A, Opercular and marginal; B, Marginal and body. C, D, Sclerites of coenenchyme. C, Branchlet; D, Stalk. b, body scale; f, flat scale; m, marginal scale; o, opercular scale; s, stellate plate; $t$, tuberculated spindle. Scale bars: $A-D=200 \mu \mathrm{m}$.

Table 3. Measurement $(\mu \mathrm{m})$ and shape of sclerites of Thouarella (Thouarella) antarctica

\begin{tabular}{lcc}
\hline \multicolumn{1}{c}{ Part } & Shape & Length $\times$ Width \\
\hline Tentacle & & None \\
Polyp body & & $213-404 \times 99-206$ \\
$\quad$ Opercular & Triangular and pointed scale & $375-581 \times 226-417$ \\
Marginal & Triangular and polygonal scale & $152-453 \times 165-343$ \\
Body & Rounded or polygonal scale & $92-253 \times 101-232$ \\
Coenenchyme of branch & Flat scale & $73-159 \times 54-138$ \\
Coenenchyme of stem & Flat scale & $118-357 \times 47-140$ \\
& Tuberculated spindle & $79-148 \times 60-149$ \\
\hline
\end{tabular}

Bayer, 2009: 34, fig. 6g-1.

Material examined. Antarctic: Potter Cove, 1 ind., 10 Jan 2010, 30-40 m deep; Potter Cove, 2 inds., 19 Jan 2010, 30-40 $\mathrm{m}$ deep; Potter Cove, 1 ind., 24 Jan 2011, $45 \mathrm{~m}$ deep.

Description. Colonies branch in a bottlebrush fashion, with one lateral branch 30-90 $\mathrm{mm}$ long at middle part (Fig. 2B).
Branchlets generally simple, sometimes branching, 16-42 (50) $\mathrm{mm}$ long, arranged at interval of $10-15$ per $\mathrm{cm}$ at stem and branch, inclined $80-85^{\circ}$ to stem arising from 5-6 sides with longitudinal rows around stem (Fig. 2B). Specimens with thin holdfast $5 \times 5-7 \times 5 \mathrm{~mm}$ in diameter, attaching pebble, $330 \times 50-450 \times 70 \mathrm{~mm}$ (height $\times$ diameter) including stalks $18-24 \mathrm{~mm}$ long. Axis stiff, bristle-like, yellow with 
golden sheen on surface, 1.0-3.0 $\mathrm{mm}$ in diameter.

Calyces isolated (not in pars of whorls), arranged in compactly spiral order on all sides of branchlets, 30-36 per cm, and inclined upward on branchlets, 30-50 (Fig. 5A). Polyps club-shaped. cylindrical, irregular in size, 0.5-1.6 0.3-0.6 $\mathrm{mm}$ (height $\times$ diameter). Polyps with six longitudinal rows of scales perfectly aligned on distal half of polyps, sometimes irregular arrangement or complete absence of scales on proximal half at adaxial side. Scales slightly overlapping, 4-5 scales at two adaxial longitudinal rows and 6-7 scales at abaxial longitudinal rows (Fig. 5B-D).

Individuals covered by a thin layer of epidermal tissue overlain by brownish cuticle. In coloration, colonies pinkish yellow (PI-10) in life and white in alcohol, showing brownish by thin membranous cuticle.

Opercular scales of polyps higher than broad, triangular and pointed with strong prominence, and a median keel running out into a shot spine, $430-650 \times 200-400 \mu \mathrm{m}$ (Fig. 6A, B). Succeeding scales from marginal to body broader than high, with small serrated upper edge, often interspersed with stronger teeth (Fig. 6A, B). Scales of coenenchyme irregular triangular to four-corned with unequal sides, 73-253 × 54-232 $\mu \mathrm{m}$ (Fig. 6C, D).

Remarks. The characteristics of our specimens mostly agree with those of Wright and Studer (1889), but they differ in the number of longitudinal rows of branchlets around the stem, and also in the number of scales overlapping at the adaxial and abaxial longitudinal rows of polyps. This species are abundantly living at a depth of $30 \mathrm{~m}$ in front of King Sejong Station.

Distribution. Antarctic (Faulkland and Crozets).

\section{Genus Onogorgia Cairns and Bayer, 2009}

Diagnosis. Colonies unbranched (flagelliform). Calyces appressed facing upwards, slightly fused basally within a whorl, arranged in whorls of up to 24. Well-developed operculum present, inner face of operculars bear multiple longitudinal ridges but no single keel. Eight marginal scales fold over operculars, forming a circumoperculum, distal edges of marginals elongate and pointed but not spinose. Polyps protected by eight longitudinal rows of body wall scales. Two abaxial rows consisting of up to 14 scales, scales on lateral rows equal in number and size to abaxials, but adaxial scales smaller and randomly arranged. Body wall scales ascus-types. Coenenchymal scales in two layers, outer layer composed of flat or ascus-types scales, inner layer composed of irregular tuberculate sclerites.

\section{Onogorgia nodosa (Molander, 1929)}

(Table 4, Figs. 2C, 7, 8)

Caligorgia nodosa Molander, 1929: 60, figs. 13, 14, Pl. a, fig. 5 (cited from Cairns and Bayer, 2009).

Ascolepis nodosa Bayer, 1981: 934, fig. 66.

Fannyella nodosa Bayer, 1998: 197, figs. 197-53-61.

Onogorgia nodosa Cairns and Bayer, 2009: 37, fig. 9h-m.

Material examined. Antarctic: Marian Cove II, 1 ind., 24 Dec 2009, 30-35 m deep; Potter Cove, 2 inds., 10 Jan 2010, 30-40 m deep; Potter Cove, 3 inds., 25 Jan 2010, 30-40 m deep; Potter Cove, 1 ind., 22 Jan 2011, 40 m deep.

Description. Colonies unbranched, flagelliform, whip-like (Fig. 2C). Specimens with thin holdfast $5 \times 2-5 \times 4 \mathrm{~mm}$ in diameter, $270 \times 2-400 \times 6 \mathrm{~mm}$ (height $\times$ diameter) including stalks $25-90 \mathrm{~mm}$ long. Axis having longitudinal grooves, $1.5-$ $2.2 \mathrm{~mm}$ in diameter at basal part, $1.3-1.6 \mathrm{~mm}$ at middle, and $0.7-1.0 \mathrm{~mm}$ at top. Coenenchyme $0.34 \mathrm{~mm}$ in thickness (Fig. 7A).

Polyps cylindrical, irregular in size, larger ones 2.5-3.9 $\times$ 0.9-1.1 mm (height $\times$ diameter), and smaller ones $1.0-2.3 \times$ 0.5-0.9 mm, directed upwards, but not strongly adhered to coenenchyme. New smaller polyps inserted between mature individuals within whorl, and also new whorl added between old whorls (Fig. 7B). About 2-3 whorls per $\mathrm{cm}$ of axial length, mostly at intervals of $1.5-2.1 \mathrm{~mm}$ and up to $4.5 \mathrm{~mm}$ at middle part of colonies. Polyps arranged in one row at each

Table 4. Measurement $(\mu \mathrm{m})$ and shape of sclerites of Onogorgia nodosa

\begin{tabular}{lcc}
\hline \multicolumn{1}{c}{ Part } & Shape & Length $\times$ Width \\
\hline Tentacle & & None \\
Polyp body & Triangular and pointed scale & $327-417 \times 65-121$ \\
Opercular & Pointed ascus-scale & $458-522 \times 156-253$ \\
Circumopercular & Serrated ascus-scale & $228-391 \times 265-408$ \\
Distal & Serrated ascus-scale & $169-384 \times 135-278$ \\
Proximal & Serrated ascus-scale & $68-159 \times 66.9-123$ \\
Body & & $118-288 \times 69-215$ \\
Coenencyme & Flat tuberculate scale & $66-204 \times 30-96$ \\
Outer cortex & Tuberculate spindle & \\
Inner canal wall &
\end{tabular}



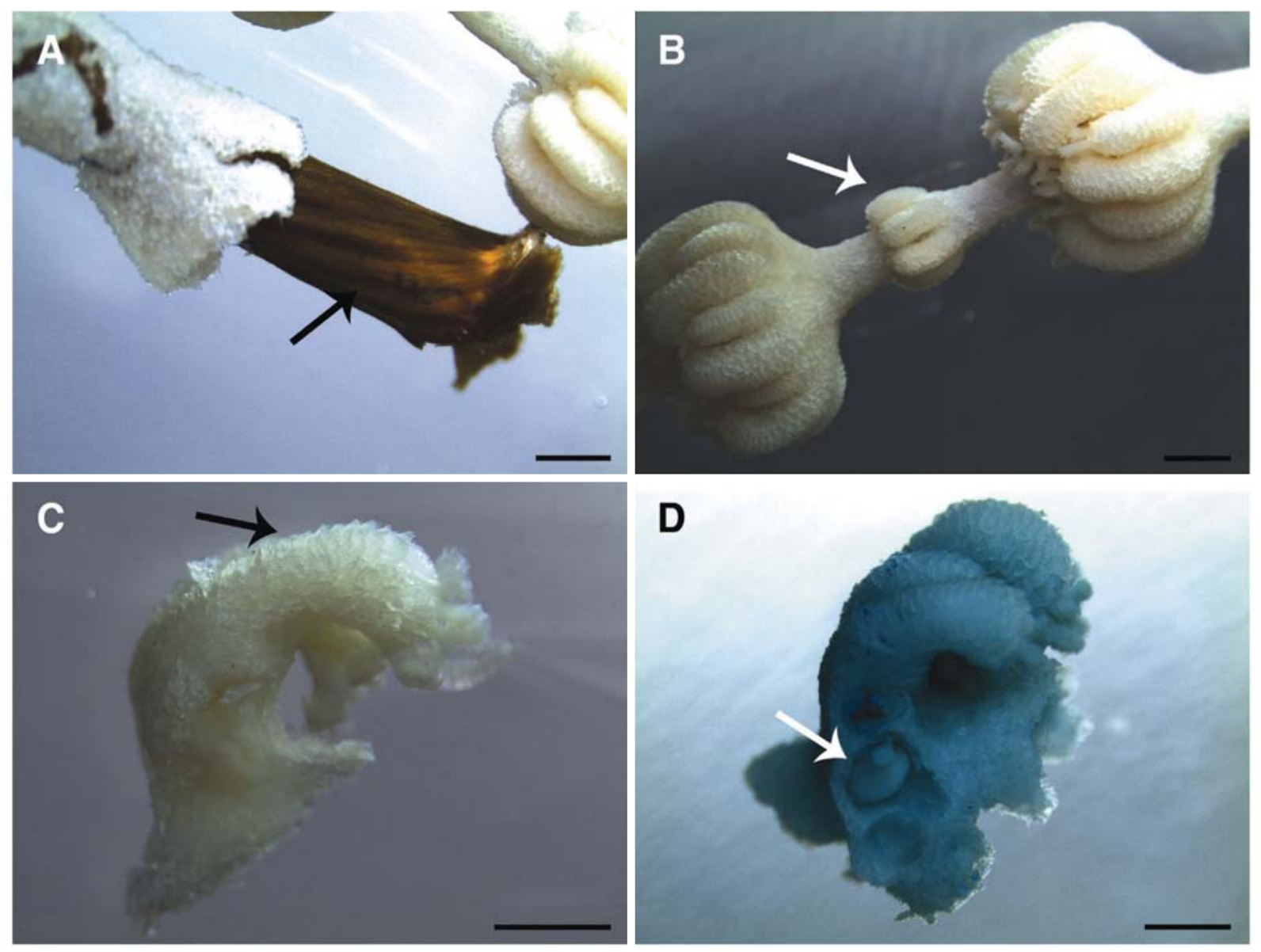

Fig. 7. Onogorgia nodosa. A, Axis with longitudinal grooves $(\downarrow)$; B, Insertion of a new whorl between two old ones; C, Abaxial and lateral side of polyp; $D, A$ gonad $(\downarrow)$ within gastrovascular cavity of polyp. Scale bars: $A-D=1 \mathrm{~mm}$.

whorl, 15-20 per whorl on low annular thickenings of coenenchyme at middle part of colonies, and 5 per whorl at lower part. Gonads large in size, $0.75 \times 0.59-1.05 \times 0.78 \mathrm{~mm}$ in diameter, similar like immature stage of embryos, but few number, approximately 1-2 per polyp within gastrovascular cavities of polyps at middle part of colonies (Fig. 7D). Scales of abaxial and lateral rows longitudinally aligned in all but basalmost part of body, circumopercular scales overreach operculars (Fig. 7C, D). Adaxial surface of polyps covered by scales in rows shorter and more or less irregular than those of abaxial surface, and they decrease toward adaxial side of polyp in size. Scales slightly overlapping, up to 20 scales at two abaxial and lateral longitudinal rows. Tentacles with 14 pairs of pinnule, $1.0-1.5 \mathrm{~mm}$ long.

In coloration, colonies pinkish yellow (PI-10) in life and white in alcohol, showing brownish by a thin layer of membranous cuticle. Axis dark brown.

Opercular scales of polyp more or less triangular and pointed, 327-417 ×65-121 $\mu \mathrm{m}$ (Fig. 8A), Circumopercular pointed ascus-scale, 458-522 × 156-253 $\mu \mathrm{m}$ (Fig. 8B). Scales decrease in size toward adaxial side of polyp, adaxial almost half size of abaxial (Fig. 8C). Coenenchyme thick, with an outer layer containing flat tuberculate scale like those on bodies of polyps, $118-288 \times 69-215 \mu \mathrm{m}$ (Fig. 8D). Inner layer, with more or less irregular rods covered by compound tuberculate spindle, 66-204 × 30-96 $\mu \mathrm{m}$.

Remarks. The characteristics of our specimens mostly agree with those of Fannyella nodosa by Bayer (1998), but they differ in the number of scales overlapping at the adaxial, lateral and abaxial longitudinal rows of polyps. This species are abundantly living at depths of $30-40 \mathrm{~m}$ in Marian Cove II and Potter Cove in front of King Sejong Station.

Distribution. Antarctic (Scotia Sea, Ross Sea, South Shetland Islands, South Georgia, and Antarctic Peninsula).

Family Isididae Lamourous, 1812

Diagnosis. Axis composed of alternating horny nodes and 

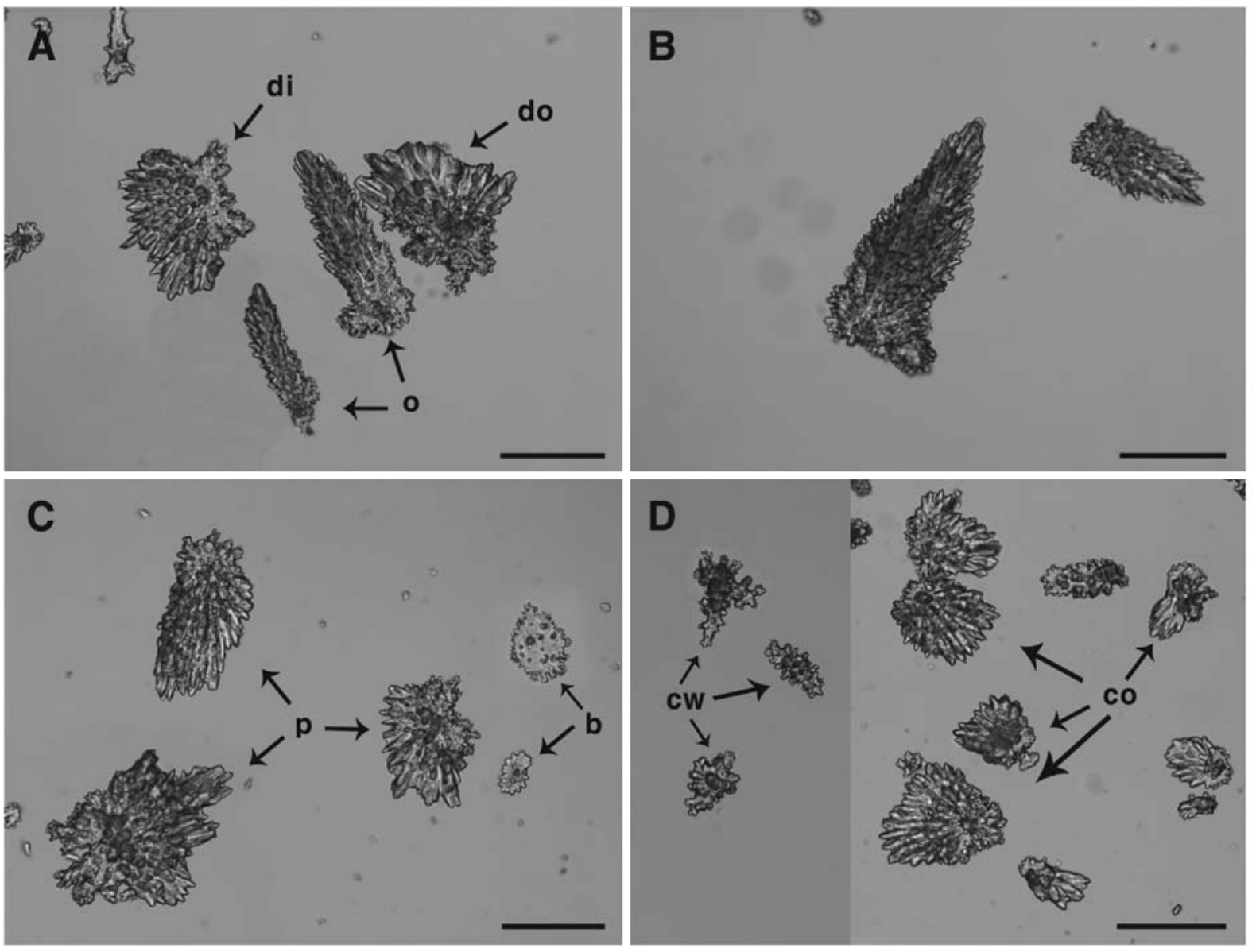

Fig. 8. Sclerites of Onogorgia nodosa. A-C, Scales of polyp. A, Opercular and distalmost; B, Circumopercular; C, Proximal and body. D, Sclerites of coenenchyme. b, body scales; co, cortex; $\mathrm{cw}$, canal wall; di, inner surface of distalmost; do, outer surface of distalmost; o, opercular; $p$, proximal. Scale bars: $A-D=200 \mu \mathrm{m}$.

non-spicular calcareous internodes. Isidids branched from internodes, in several planes or all sides in form of bottlebrush. Polyps cylindrical or clavate, standing straight or inclined from axis, sometimes recurved toward axis, scattered on all sides of branches. Sclerites in form of serrated scales or plates, sometimes narrow and fusiform, transversely place in polyps. Bases of tentacles armed with converging scales.

\section{Genus Tenuisis Bayer and Stefani, 1987}

Diagnosis. Very slender isidids sparsely dichotomously branched from internodes, occasionally from nodes. Internodes cylindrical, solid, slightly enlarged at each end, smooth or with only faint longitudinal striation confined to larger branches and main stem. Polyps tall, narrowly campanulate, usually 1 or 2 per internodes. Sclerites of polyps flat scales never projecting between tentacle bases, spindles or rods. Sclerites of coenenchyme small, thin scales with dentate margins.

\section{Tenuisis microspiculata (Molander, 1929)}

(Table 5, Figs. 2D, 9, 10)

Ceratoisis microspiculata Molander, 1929: 78, fig. 26, Pl. 5, fig. 8 (cited from Cairns and Bayer, 2009).

Tenuisis microspiculata Bayer and Stefani, 1987: 978, figs. 24-27.

Material examined. Antarctic: Potter Cove, 1 ind., 10 Jan 2010, 30-35 m deep; Marian Cove II, 1 ind., 15 Jan 2010, 3035 m deep; Marian Cove II, 1 ind., 18 Jan 2010, 30-35 m deep; Potter Cove, 1 ind., 25 Jan 2010, $35 \mathrm{~m}$ deep.

Description. Specimens with thin holdfast $3 \times 4-7 \times 5 \mathrm{~mm}$ in diameter, almost one plane, $80 \times 50 \times 20-190 \times 120 \times 30 \mathrm{~mm}$ (height $\times$ width $\times$ thickness) including stalks $10-22 \mathrm{~mm}$ long (Fig. 2D). Colonies dichotomously branched from mostly internodes and sometimes nodes at upper part of colonies (Fig. 9A). 1st branches 12-15 mm long, longer and longer towards top of colonies, 8th 20-40 mm long. At angles of 

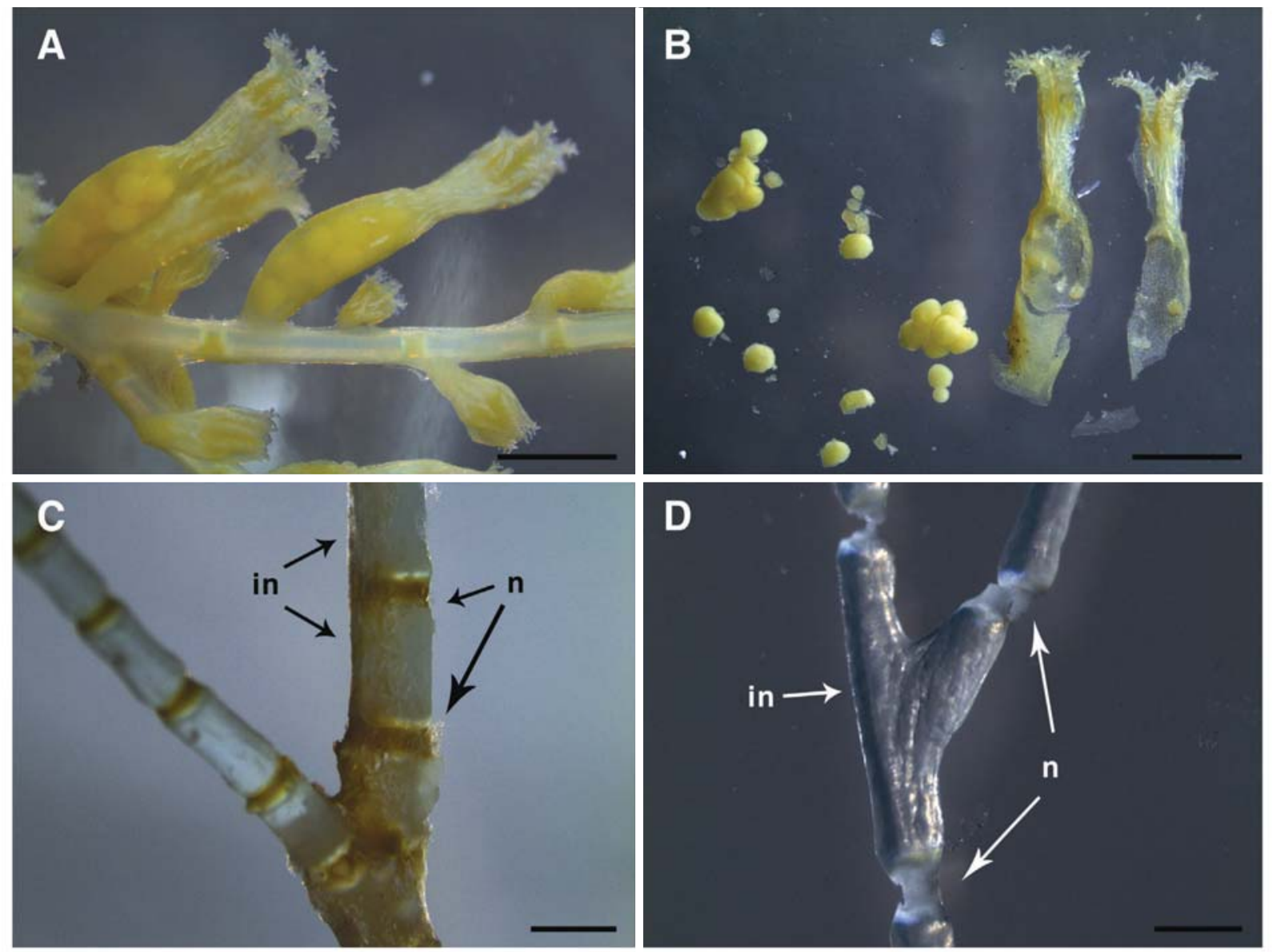

Fig. 9. Tenuisis microspiculata. A, Arrangement of polyps on branch; B, A polyp and gonads within the polyp; $C$, Axis covered with coenenchyme; $D$, Axis without coenenchyme. in, internode; $n$, modes. Scale bars: $A-C=1 \mathrm{~mm}, D=0.5 \mathrm{~mm}$.

Table 5. Measurement $(\mu \mathrm{m})$ and shape of sclerites of Tenuisis microspiculata

\begin{tabular}{lcc}
\hline \multicolumn{1}{c}{ Part } & Shape & Length $\times$ Width \\
\hline Tentacle & Narrow flat spindle (rodlet) & $9-169 \times 20-57$ \\
& Curved scale & $84-142 \times 13-36$ \\
Pinnule & Needle & $14-36 \times 1-2.5$ \\
Polyp body (verruca) & Flat elongated spindle & $189-252 \times 64-80$ \\
& Elongate spindle & $200-308 \times 27-52$ \\
Coenencyme & Serrated scale (rare) & $298 \times 85$ \\
& Flat elongated spindle & $98-118 \times 31-38$ \\
& Elongate spindle & $86-178 \times 17-26$ \\
& Thornscale & $222 \times 105,249-278 \times 81-92$ \\
\end{tabular}

branching, 1 st $60-90^{\circ}$ and narrower and narrower towards 8 th $30^{\circ}$. Nodes brownish, $0.06-0.32 \times 0.01-0.91 \mathrm{~mm}$ (length $\times$ diameter), in detail $0.20-0.32 \times 0.72-0.91 \mathrm{~mm}$ at lower part of colonies, $0.20-0.22 \times 0.34-0.53 \mathrm{~mm}$ at middle, and 0.06$0.12 \times 0.01 \mathrm{~mm}$ at upper. Internodes whitish, sculptured lower longitudinal groove (Fig. 9D), 0.50-1.83 ×0.17-1.00 mm long (length $\times$ diameter), in detail $0.50-1.50 \times 0.55-1.00 \mathrm{~mm}$ at lower part of colonies, $1.30-1.83 \times 0.50-0.60 \mathrm{~mm}$ at middle, and 1.26-1.31 $\times 0.17-0.18 \mathrm{~mm}$ at upper (Fig. 9C, D).

Polyps irregular in size, $0.4-3.0 \times 0.2-0.7 \mathrm{~mm}$ (height $\times$ diameter), smaller ones $0.4-0.8 \times 0.2-0.3 \mathrm{~mm}$ and larger ones $1.6-3.0 \times 0.5-0.7 \mathrm{~mm}$, trumpet-shaped, standing $40-50^{\circ}$ to 

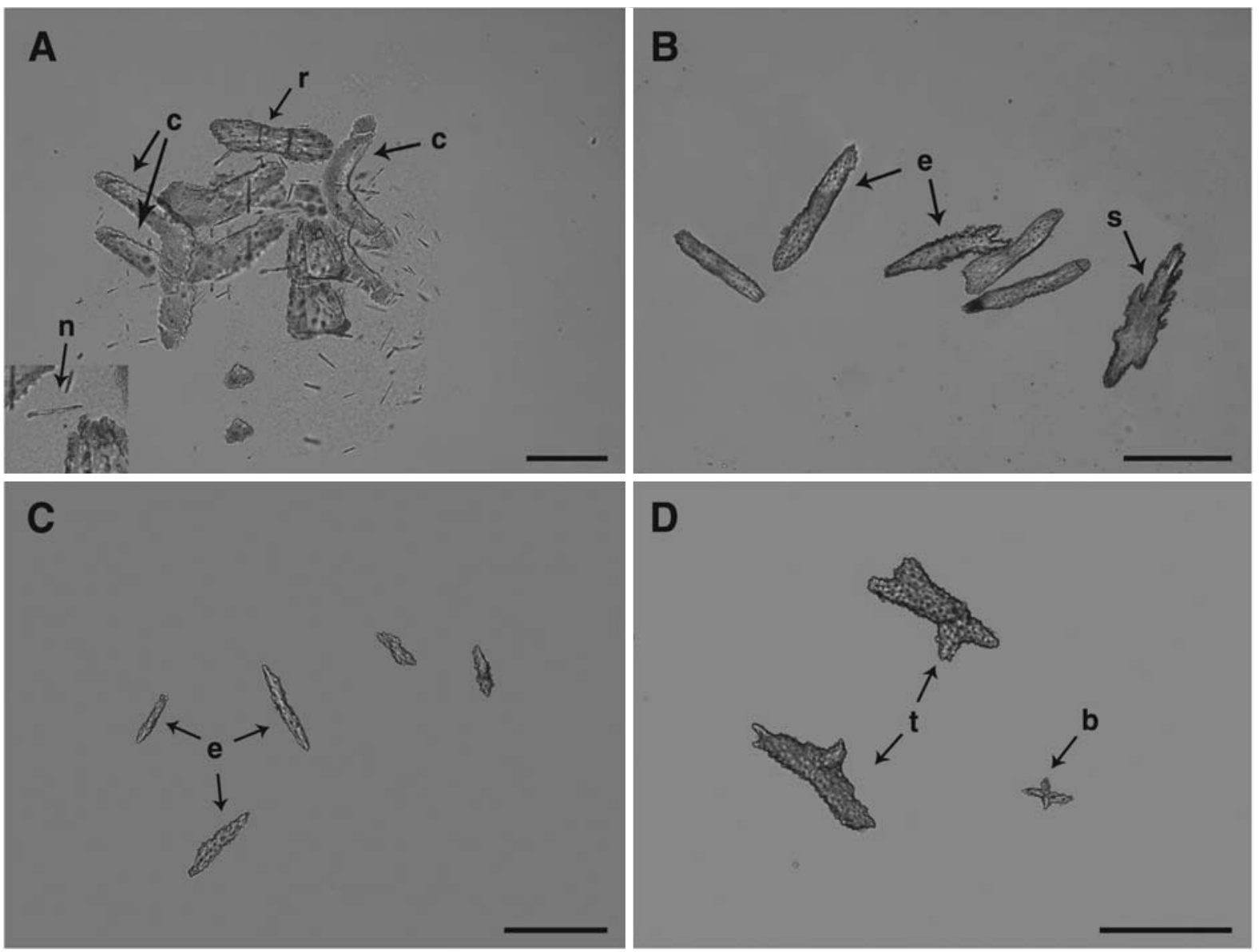

Fig. 10. Sclerites of Tenuisis microspiculata. A, B, Sclerites of polyps. A, Tentacle and pinnule; B, Verruca. C, D, Sclerites of coenencyme. $b$, branched scale; $c$, curved scale; e, elongated spindle; $n$, needle; $r$, rodlet; $s$, serrated scale; $t$, thornscale. Scale bars: $A=$ $100 \mu \mathrm{m}, \mathrm{B}-\mathrm{D}=200 \mu \mathrm{m}$.

axis, and arranged alternately at intervals of $0.5-2.0 \mathrm{~mm}, 11-$ 16 per $\mathrm{cm}$ in number of polyps, usually one or occasionally two per internode, all around branches (Fig. 9A). Larger polyps usually arising from every node and one or two smaller polyps between larger ones. Individuals covered by a thin layer of epidermal tissue overlain by cuticle. Gonads 50-286 $\mu \mathrm{m}$ in diameter, up to 35 per polyp, well developed within gastrovascular cavities of polyps at upper part of colonies (Fig. 9A, B). Tentacles with 10-11 pairs of pinnules, 0.5-1.0 $\mathrm{mm}$ long. Coenenchyme very thin membranous, $117-120 \mu \mathrm{m}$ in thickness (Fig. 9C).

In coloration, colonies white, polyps showing yellowish orange by thin membranous cuticle.

Distal half of polyp body, beneath tentacle, contains a single layer of flat, elongated scales longitudinally arranged, distalmost sclerites weakly converging in 8 indistinct points. Polyp sclerites short, flat elongated spindles, cylinders and clubs, sparsely thorned, 190-308 $\mu \mathrm{m}$ long, narrow curved scales up to $0.3 \mathrm{~mm}$ long (Fig. 10A, B). Pinnules minute rodlets $14-36 \mu \mathrm{m}$ long, and larger rodlets flattened and marginally lobate. At distal part of polyp body, a single layer of flat. Sclerites of coenenchyme flat elongated spindles and thornscales, sparsely visualized in membranous tissue (Fig. 10C, D).

Remarks. The characteristics of our specimens mostly agree with those of Bayer and Stefani (1987), but they differ in the size and shape of sclerites of the verrucal wall.

Distribution. South Atlantic (South Shetland Islands), Antarctic Peninsula (Graham Land, Palmer Land, Viecennes Bay, and Wikes Land).

\section{ACKNOWLEDGMENTS}

This research was supported by a grant from Korea Polar Research Institute of KORDI and a part of the project titled "Korean Coral Resources Bank (KCRB)" funded by the Mi- 
nistry of Land, Transport and Maritime Affairs, Korea.

\section{REFERENCES}

Bayer FM, 1956. "Octocorallia”. In: Treatise on Invertebrate Paleontology (Ed., Moore RC). University of Kansas Press, Lawrence, KS, pp. F166-F189, F192-F211.

Bayer FM, 1981. Key to the genera of Octocorallia exclusive of Pennatulacea (Coelenterata: Anthozoa), with diagnoses of new taxa. Proceedings of the Biological Society of Washington, 94:902-947.

Bayer FM, 1998. A review of the circumaustral gorgonacean genus Fannyella Gray, 1870 with descriptions of five new species. Senckenbergiana Biologica, 77:161-204.

Bayer FM, Stefani J, 1987. New and previously known taxa of isidid octocorals (Coelenterata: Gorgonacea), partly from Antarctic waters. Proceedings of the Biological Society of Washington, 100:937-991.

Bayer FM, Stefani J, 1989. Primnoidae (Gorgonacea) De Nouvelle-Calédonie. Bulletin de Museum National d'Histoire Naturelle. Paris, Serie 4, 10:449-518.

Cairns SD, 2006. Studies on western Atlantic Octocorallia
(Coelenterata: Anthozoa). Part 6. The genera Primnoella Gray, 1858, Thouarella Gray, 1870, Dasystenella Versleys, 1906. Proceedings of the Biological Society of Washington, 119:161-194.

Cairns SD, Bayer FM, 2009. A generic revision and phylogenetic analysis of the Primnoidae (Cnidaria: Octocorallia). Smithsonian Contributions to Zoology, 629:1-79.

López-González PJ, Gili JM, Orejas C, 2002. A new primnoid genus (Anthozoa: Octocorallia) from the Southern Ocean. Scientia Marina, 66:383-397.

Milne Edwards H, 1857. Histoire Naturelle des Coralliares ou Polypes Proprement Dits. Librairie Encyclopedique de Roret, Paris, 1:1-326.

Versluys J, 1906. Die Gorgoniden Des Siboga-Expedition, II. Die Primnoidae. Siboga-Expeditie, 13a:1-187.

Wright EP, Studer T, 1889. Report on the Alcyonaria collected by H.M.S. Challenger during the years 1873-76. Report on the Scientific Results of the Voyage of H.M.S. Challenger during the years 1873-76, Zoology, 31:1-314.

Received February 17, 2012 Revised March 26, 2012 Accepted March 29, 2012 